\title{
Managing Cartels: how Cartel Participants Create Stability in the Absence of law
}

\author{
J. D. Jaspers ${ }^{1}$
}

Published online: 16 September 2016

(C) The Author(s) 2016. This article is published with open access at Springerlink.com

\begin{abstract}
Firms enter cartels (e.g. price-fixing; bid-rigging) in order to control market uncertainties and gain collusive profits, but face challenges in controlling the cartel itself. A challenge for business cartels is how to organise collective illegal activities without the use of formal control, such as binding legal contracts or arbitration. While one might expect that a lack of formal legal control leads to mutual conflicts and opportunistic behaviour resulting in short-lived cartels, firms often manage to continue their illegal conduct for years. This raises questions as to how firms organise their cartels in the absence of legal means. This article addresses how informal coordinating mechanisms enable cartel stability outside the scope of formal legal control. Based on an in depth study of 14 Dutch cartels, this article shows the importance of informal social mechanisms to coordinate, monitor, enforce, and compensate for the longevity of business cartels. Furthermore, the results emphasise that in order to explain cartel stability, social mechanisms that induce trust need to be considered.
\end{abstract}

Keywords Business cartels · Corporate crime · Informal social control · White-collar crime

\section{Introduction}

Business cartels are an example of corporate and economic crime that entail collusion between competitors to fix prices, divide markets, or rig tendering procedures (Friedrichs 2010; Stewart 2007; Geis 1987). Cartels initially enable firms ${ }^{1}$ to minimalise uncertainties and the risks of a competitive market. However, once in a cartel, firms face various external and internal threats

\footnotetext{
${ }^{1}$ Admittedly, there are issues of agency within firms that influence the outcome of corporate conduct. However, I will not deal with that issue here and will consider firms simply as economic entities.

J. D. Jaspers

jaspers@law.eur.nl
}

1 Department of Criminology at the Erasmus University Rotterdam (the Netherlands), Burgemeester Oudlaan 50, 3000DRRotterdam J5-19, The Netherlands 
to the cartel itself. Internal threats involve cheating, not complying with the cartel, and defection, insiders denouncing the cartel using leniency. ${ }^{2}$ Cartelists need to deal with these threats in an informal setting. In other words, cartels require collective action, but participants have to operate subversively, against the background of increasing criminalisation ${ }^{3}$ of this conduct in recent years. Cartelists are therefore unable to formulate binding contracts or resort to legal conflict resolution in the event of broken agreements.

Business cartels are, in that sense, comparable to organized crime. From organized crime literature, we know that non-violent forms of dispute settlement are common and often prove to be a less costly business tool than violence, in illegal contexts (Paoli 2003; Zaitch 2002). Violent retaliation can attract unwanted attention from authorities and harm 'business' relations and reputations of reliability in illegal markets (Zaitch 2005). Studies on drug markets show that non-violent retaliation in the form of negotiation, avoidance and toleration reduces the costs of conflict and is widespread (Jacques and Wright 2008, 2011). In analogy to the study of organized crime, the aim of this article is to investigate how legitimate firms manage their illegal agreements with others and how they deal with the risks of cheating, free riding and defection.

The question how firms manage to stabilise cartels has received limited attention in criminological literature. There are some criminological white-collar crime studies on cartel conduct, like the seminal study of Geis (1987) on price-fixing in the heavy electrical equipment industry. These studies explain cartel conduct by a need to manage and avoid uncertainties, make results more predictable and minimise risks (Agnew et al. 2009; Paternoster and Simpson 1996; Jamieson 1994; Geis 1987; Sonnenfeld and Lawrence 1978). However, these studies do not adopt a longitudinal perspective to cartels. To the extent that studies do adopt a longitudinal approach to white-collar crime, they focus on the individual life course, instead of on co-offending (Piquero and Weisburd 2009; Piquero 2012; Weisburd and Waring 2001).

In economic literature, numerous studies $d o$ focus on how firms manage to stabilize cartels (Harrington 2006; Hinloopen 2006; Ashenfelter and Graddy 2005; Spagnolo 2000; Spar 1994; Stigler 1968). Economists mostly perceive cartels as 'inherently unstable', focusing on the incentives to cheat and means of retaliation in order to prevent cheating. The image of cartels as 'inherently unstable' is influential and underpins competition law and policy. Accordingly, the legal debate focuses on raising regulatory pressure in order to destabilise existing cartel agreements. This inherent instability is not in line with the empirical evidence of the duration of cartels. Cartels manage to exist for years - even decades (Levenstein and Suslow 2006; Leslie 2008; Connor 2010; Connor and Helmers 2007) — and they often comprise a relatively large number of participating firms (Connor 2010). The criminalisation project therefore seems ill informed by a proper understanding of the operation of business cartels (Beaton-Wells and Haines 2010; Harding 2006; Harding and Joshua 2003: 284).

This article contributes to a more complete understanding of the operation of cartel stability, by addressing the question how cartels operate in secrecy, confronted with coordination problems and instability and how they deal with mutual disagreements in the absence of legal

\footnotetext{
${ }^{2}$ Leniency is a whistleblowing instrument through which firms can come forward to competition authorities with substantial evidence regarding the cartel in return for sanction immunity or waivers of prosecution.

${ }^{3}$ Since the late $1990 \mathrm{~s}$, most countries introduced administrative penalties, and some countries have imposed criminal sanctions for cartel conduct (Beaton-Wells 2008; Ottow 2012). Today, scholars speak of a global trend of cartel criminalisation, with more than 30 countries worldwide using criminal law to sanction cartels and most other countries, the European Union and its member states in particular, having increased the level of fines significantly over the last two decades (Harding et al. 2015; Shaffer and Nesbitt 2011).
} 
means. To review the scholarship on cartel stability, it is helpful to distinguish two directions of thought. The first and most dominant approach is an economic one that focuses on a lack of trust between cartelists and on their individual incentives to cheat. The second approach is a social one that focuses on the impact of social mechanisms that enable trust between cartelists. As regards cartel stability, these contrasting approaches result in two explanatory models that generate different expectations as to how members stabilise their cartels in the absence of legal means.

In an empirical manner, this article investigates different responses of cartelists to assess the validity of existing theoretical explanations concerning cartel stability. Therefore, the question is posed: How do informal coordinating mechanisms enable cartel stability outside the scope of formal legal control and what role does trust play?

Based on 14 case studies of Dutch cartels, this article explores how cartels manage to survive for years despite the threat of cheating and detection; how do firms organise cartels; and how do they prevent and overcome internal conflicts? Section 2 of the paper discusses previous studies and theory concerning cartel stability. Section 3 introduces data and the methods used for this study. Section 4 addresses the internal mechanisms of coordination, monitoring, compensation, and enforcement in light of the research question. Section 5 deals with the conclusions, limitations, and possibilities for further research.

\section{To Cheat or not to Cheat: Theoretical Perspectives on Cartel Stability}

\section{The Economic Perspective: Stability Through Retaliation}

Economic literature on cartels uses a model that departs from the idea of a lack of trust between member firms. In this model, firms are bound to cheat on the mutual agreement because of incentives to do so. Economic studies perceive cartels in terms of a game-theoretical problem: it starts from the idea that cartel participants are motivated instrumentally, and the perceived costs and benefits are part of a rational assessment. With this comes a focus on incentives for players in the cartel to cheat, such as overselling or underpricing (Stigler 1968). Firms will do so in order to maximise individual profits further or to expand market shares beyond the cartel's collective agreement. This leads to the perceived 'inherent instability' of cartels (Rapoport and Chammah 1965). This model is vividly illustrated by one of the directors of $\mathrm{ADM}$ in the lysine cartel ${ }^{4}$ : 'Everybody's going to want to cheat anyway. Knowing them, we will want to cheat' (Leslie 2004: 561; Eichenwald 2001: 220).

In this perspective, cartel stability depends on the perceived losses and profits that result from cheating in relation to the likelihood of possible punishment from other cartel members. Therefore, cartelists can only establish stability by means of a system that increases - by way of internal punishment - the costs of cheating (Spagnolo 2000; Spar 1994). Cartels need to monitor their agreement to detect cheating and punish firms that practise it (Levenstein and Suslow 2006; Connor 2001; Ayres 1987). Thus, in order for a cartel to survive, this model assumes credible punishment should be in place to penalise members that cheat, thereby

\footnotetext{
${ }^{4}$ The international lysine cartel entailed a price-fixing conspiracy between the American food processing company Archer Daniel Midland and its main Korean and Japanese competitors around the animal feed additive lysine. Cartelists allegedly managed to raise global prices of lysine by $70 \%$ for several years during the mid1990 s.
} 
enforcing the cartel agreement (Ayres 1987; Green and Porter 1984; Stigler 1968). Forms of credible punishments described are price slicing and the threat of price wars (Harrington 2006; Grossman 1996). For instance, when firms observe cheating by other firms, they lower their cartel prices temporarily in order to punish possible cheaters and to stabilise the cartel (Ashenfelter and Graddy 2005).

In short, an economic approach seeks explanations for cartel stability in effective internal detection and punishment. This introduces the expectation that the cases will demonstrate sophisticated systems of coordination, monitoring, and enforcement. Retaliation in the form of price slicing and price wars will serve to increase the costs of cheating, thus ultimately stabilising cartels.

Recent empirical studies, find two important issues regarding cartel stability that challenge the assumptions in the economic model. Firstly, cartels invest more in means to prevent cheating than to resort to ex post punishments, ${ }^{5}$ which are costly (Harrington 2006; Levenstein and Suslow 2006). Secondly, a retaliatory response to cheating increases the likelihood of a cartel's natural demise (Levenstein and Suslow 2011). Where strong systems of monitoring and enforcement are considered to account for cartel stability in the economic model, empirical results suggest otherwise. The deviating effects of internal punishments leave room for alternative explanations for the longevity of cartels.

\section{The Social Perspective: Stability Through Mutual Trust}

Empirical cartel studies that use a social approach criticise economic assumptions on behaviour as being too simplistic (Parker 2012). Results from the Melbourne cartel project $^{6}$ show the discrepancies between economic assumptions in competition policies and the social reality of business conduct (Parker 2012; Haines and Beaton-Wells 2012). A social approach examines the relation between actors rather than focusing on the individual agent. It considers the actions of individuals to be strongly socially embedded. A social approach considers cartels in the context of mutual trust, focusing on the incentives of firms to act cooperatively in the informal setting of cartels. Trust may provide an important element in explaining how firms manage to operate their cartels for long periods (Stephan 2010; Leslie 2004), and better account for some of the recent empirical findings on cartel stability.

Empirical studies using a social approach to cartel stability are scarce, but we can find similar explanations for cooperative behaviour in studies on legal business conduct in informal settings; this is referred to as 'the shadow of the law'. It shows that business relations are socially embedded and able to generate social norms that make legal sanctions

\footnotetext{
${ }^{5}$ In this regard, I point out the importance of compensation systems, such as side payments and buy-backs. These are financial compensations or compensations in kind, and serve to even out disparities regarding, for instance, agreed-upon volumes at the end of the year. I classify them here as a means of coordination in order to regulate the execution of the agreement and to prevent miscommunications or conflicts. This has to be distinguished from punishment by retaliation as a response to conflicts.

${ }^{6}$ This research project was conducted at the Melbourne Law School by researchers Caron Beaton-Wells, Fiona Haines, Christine Parker, David Round, and Janette Nankivell. The project studied the process of cartel criminalisation and the perceptions of the general public and business professionals with regard to cartel conduct. Researchers used a multidisciplinary approach, including legal and social research methods. For more information, see http://www.law.unimelb.edu.au/cartel.
} 
unnecessary and superfluous (Ellickson 1991; Granovetter 1985; Black 1983, 1984; Macaulay 1963, 2013). ${ }^{7}$ Scholars in economic sociology have stressed the argument and the paradox of the social embeddedness of economic action, claiming that the more an informal economy approaches the model of a 'true market', the more it depends on social ties. Social embeddedness is considered especially visible in a context where mutual trust is the only resource against malfeasance (Portes 2010; Granovetter 1993). Therefore, in the absence of enforceable legal protection, personal relations between cartelists are expected to form an important factor for the internal stability of cartels. Stephan (2010: 361) states: 'The notion that one should befriend individuals in business and bring them into one's home can be an explicit social mechanism for ensuring that an agreement is honored in the absence of strong legal protection'. Personal relations and interpersonal trust can account for cartel stability, and three main conditions for interpersonal trust can be identified: communication, reciprocity and reputation.

Communication Common protocols and frequent communication can play a significant role in the process of building trust. People who communicate frequently are more likely to perceive mutual trust (Leslie 2004: 538). Face-to-face meetings and coordination will facilitate the perception of trustworthiness, thus promoting cooperative behaviour. Just as in the economic approach, systems of coordination and monitoring are expected here. The social approach perceives these systems as a symptom of the incentives to cooperate and as a means to build trust, thus making punishments irrelevant. Moreover, simply allowing discussions and participating in negotiations increases cooperative behaviour within cartels, creating more internal support and legitimacy for the agreement and its conditions (Leslie 2004: 544). Therefore, instead of retaliation, negotiation and mediation are expected in response to mutual disagreements.

Reciprocity In the operation of cartels, firms will build upon mutual rights and obligations because of the coordination of agreements and the compensation in light of them (Van de Bunt 2010; Hertogh 2005). This enables norms of generalised reciprocity to develop within the cartel. Being in debt to others and having others indebted to you affects one's actions. It is expected that this creates mutual dependencies between firms, which in turn promotes peaceful arbitration and discourages cheating, thus ultimately stabilising the cartel.

Reputation A reputation for being trustworthy is crucial in business relations (Van Erp 2008). One's promise of trustworthiness must be credible, as trust is a function of expectations (Leslie 2004: 540). Having a shared past serves as input for this reputation, and having a shared future creates a need for it, again giving firms an interest in handling their relations in a harmonious manner. The desire for a positive reputation encourages parties to avoid mutual conflict or retaliation (Posner 2009). Retaliation, such as price wars, can be an expensive piece of 'equipment' in business relations. Firms thrive on being perceived by others as being a trustworthy, cooperative and reasonable partner.

\footnotetext{
${ }^{7}$ The ability of people to work together for common purposes in groups and organisations has also been defined as social capital by a group of influential scholars within the field of sociology (Coleman 1988; Fukuyama 1995; Putnam 1995). Fukuyama (1997: 378-9) says: 'Social capital can be defined simply as the existence of a certain set of informal values or norms shared among members of a group that permit cooperation among them (...) the norms (...) include virtues like truth-telling, the meeting of obligations, and reciprocity'. Putnam (2000; 19) also stresses the importance of norms of reciprocity and trustworthiness that arise from social networks.
} 
Table 1 depicts the two explanatory models of cartel stability. Both approaches expect similar organisation within cartels: namely, systems of coordination and monitoring. However, they foresee different responses in light of internal cheating: the economic approach expects retaliation and the social approach anticipates negotiation. The models contain ideal types, the cases that are studied and discussed are viewed in regard to these models to assess which elements they contain in practice.

\section{Methods and Data Sources}

This article examines cartel stability based on a qualitative case file analysis of 14 Dutch cases. In these cases, the Dutch Competition Authority imposed an administrative fine between October 2007 and January $2012 .{ }^{8}$ These cases were selected because reports that led to a fine contain substantial proof, including documentation on coordination and communication within cartels. This documentation allowed for a systematic and in-depth study of the structure and nature of cartels. The 14 cases were examined using document analysis and semi-structured interviews with case managers from the Authority for Consumers and Markets. The sources are official reports by the authority, ${ }^{9}$ summarising the files and containing a selection of evidence used in administrative proceedings towards administrative fines imposed upon corporations. These files contain descriptions of the modus operandi of cartels, and include correspondence between their members; transcriptions of verbal interrogations with corporate officials by the competition authority; and sources of cartel administration. These statements are supported by additional written administration. The material was systematically studied using a checklist, focusing on the type of network; the nature of mutual relations; mechanisms for mutual control; mechanisms for mutual trust; and instances of cheating and conflicts. For every case, the document analysis was complemented with a semi-structured interview with the project manager of the authority that handled the investigation. In these interviews, the following topics were discussed: the nature of the cartel; mechanisms for mutual control and trust; and instances of cheating and mutual conflicts. These interviews served to provide a better overview of the files and an opportunity to ask additional questions that could not be answered in full through studying the written reports.

The use of secondary sources leads to several limitations of this study. Because of detection and enforcement biases, the cases do not necessarily provide a representative image of all cartel conduct in the Netherlands. Some cartels have greater chances of being detected, and cases that involve substantial proof will have a greater chance of ultimately resulting in an administrative fine. The statements of corporate officials referred to in this article, originate from secondary sources and therefore might express firms' perspectives, but were originally made in the course of an administrative procedure. Note that one of the formal legal

\footnotetext{
${ }^{8}$ Commissioning administrative fines is one of the possible sanctions authorised by Dutch competition law (according to Art. 56 lid 1 sub a Mw). Since October 2007, Dutch competition law allows the investigation of private property and the possibility of fining natural persons (Kamerstukken I 2006/07, 30 071, A). October 2007 is the starting point of the analysis for the sake of comparability of the material. January 2012 is indicated as end date because cases usually take several years from the initial investigation until the official sanction; all cases completed by January 2012 have been included.

${ }^{9}$ These files are a result of investigations based on the legal power invested in the Dutch competition authority to interrogate corporate officials and demand corporate intelligence (Art. 5:16 Awb), to investigate company and private property and administration (Art. 5:15, art. 54, $55 \mathrm{Mw}$ ), and to use leniency requests and other relevant informants and public information.
} 
Table 1 Two ideal typical explanatory models of cartel stability

\begin{tabular}{|c|c|c|}
\hline Model & Economic approach & Social approach \\
\hline $\begin{array}{l}\text { Underlying behavioural } \\
\text { assumptions }\end{array}$ & $\begin{array}{l}\text { Instrumentally oriented } \\
\text { economic action: } \\
\text {-Instrumentally motivated actors } \\
\text {-Mutual lack of trust central } \\
\text {-Focuses on the incentives to cheat: } \\
\text {--maximise profits } \\
\text {--expand markets }\end{array}$ & $\begin{array}{l}\text { Socially oriented economic action: } \\
\text {-Normatively motivated actors } \\
\text {-Mutual trust central } \\
\text {-Focuses on the incentives to cooperate: } \\
\text {--value introjection }\end{array}$ \\
\hline Organisation of cartels & $\begin{array}{l}\text { As a result of lack of trust and } \\
\text { incentives to cheat: } \\
\text {-Systems of coordination and monitoring }\end{array}$ & $\begin{array}{l}\text { As a result of social ties, means to build } \\
\text { trust, and the incentives to cooperate: } \\
\text {-Systems of coordination and monitoring }\end{array}$ \\
\hline $\begin{array}{l}\text { Expected response } \\
\text { to cheating }\end{array}$ & Punishment/retaliation & Mediation/negotiation \\
\hline Expected outcome & $\begin{array}{l}\text { Forced compliance of cheating firm } \\
\text { to original agreement, or exclusion } \\
\text { of cheater }\end{array}$ & $\begin{array}{l}\text { Adjusted agreement } \\
\text { and/or compensation scheme and } \\
\text { continuation of the cartel }\end{array}$ \\
\hline
\end{tabular}

requirements of finding a person or corporation guilty of an infringement is that the effects of the infringement must be 'noticeable'; have a significant effect on the market. This might lead some of the corporate officials to deny the 'real' effect of any agreements made, as a legal defence strategy, or to under-report their conduct in general. Table 2 presents descriptive information on the selected cases, including the cartel's duration, ${ }^{10}$ number of firms, and nature of the conduct. ${ }^{11}$ The relatively high number of firms in these cases can be biased because of three main issues. Firstly, cartels with an active industry association have a greater chance of detection. Secondly, cartels with a more limited number of firms may conspire more effectively, with little chance of detection. Thirdly, an effective cartel may have a self-amplifying effect; the collusion can offer more firms an opportunity to survive.

The Dutch cases in this study have an average duration of about five years, which is comparable to the typical duration of cartels (Levenstein and Suslow 2006, 2011). This duration shows that firms manage to stabilise their cartel for several years, which indicates a form of stability and effective coordination. Besides duration, most of the cases involve a large number of participating firms. For instance, 15 firms were involved in cases 7 and 9. It indicates the need for systems of communication and monitoring in coordinating collective action in cartels.

Table 2 also states the nature of the conduct. Three main categories are distinguished: bidrigging, price-fixing and market division or allocation. Based on legal definitions, these serve as a descriptive label, indicating the main category of the infringement, though these categories are not mutually exclusive per se. Bid-rigging involves firms in a tendering procedure, communicating before the bidding takes place. They divide the work and rotate bids, thereby

\footnotetext{
${ }^{10}$ To determine the duration of these cartels, the period of the continuous infringement stated in the report is used. This also means that the period before the introduction of the Dutch cartel prohibition (January 1998) is not incorporated in determining the duration. This suggests an underestimation of the actual duration of the cartel. This effect is enhanced by the internal selection bias of the competition authority concerning the minimum standards regarding evidence.

${ }^{11}$ In light of confidentiality, the industry in which the cartels took place cannot be indicated per case in Table 2. The cases took place in the following industries; construction (6); heavy industry (3); general services industry (2); forestry (1); waste disposal (1); and financial services (1).
} 
Table 2 Descriptive information on selected cartel cases

\begin{tabular}{lllll}
\hline Case \# & $\begin{array}{l}\text { Duration in } \\
\text { years }\end{array}$ & $\begin{array}{l}\text { Number of } \\
\text { firms }\end{array}$ & $\begin{array}{l}\text { Nature of the } \\
\text { conduct }\end{array}$ & $\begin{array}{l}\text { Collective } \\
\text { market share }\end{array}$ \\
\hline Case 1 & 6 & 9 & Market division & $70 \%$ \\
Case 2 & 8 & 9 & Price-fixing & $85-90 \%$ \\
Case 3 & 6 & 8 & Bid-rigging & $60-80 \%$ \\
Case 4 & 6 & 5 & Market division & $60-80 \%$ \\
Case 5 & 6 & 5 & Bid-rigging & - \\
Case 6 & 1 & 9 & Bid-rigging & - \\
Case 7 & 7 & 15 & Market division & $90 \%$ \\
Case 8 & 1 & 2 & Bid-rigging & - \\
Case 9 & 6 & 15 & Market division & $87.3 \%$ \\
Case 10 & 1.5 & 4 & Price-fixing & $58 \%$ \\
Case 11 & 2 & 3 & Bid-rigging & $85-95 \%$ \\
Case 12 & 9 & 14 & Bid-rigging & - \\
Case 13 & 3.5 & 10 & Market allocation & - \\
Case 14 & 11 & 4 & Market allocation & $35-50 \%$ \\
\hline
\end{tabular}

rigging the procedure. Also known as collusive tendering, it generally involves raising price offers to the buyer. In price-fixing cartels, firms make explicit agreements on the price or surcharge of a particular product or service. Firms will use, for instance, minimum pricelists. The other cases are market division or allocation. In these cartels, firms agree to fix market shares or divide markets into geographical regions.

\section{Managing Cartels in the Absence of Formal Legal Control}

To analyse which elements of the two approaches occur in the cases, they are discussed in light of the explanatory model provided in Section 2: respectively, the organisation of cartels, the responses to cheating and conflicts, and the outcome of these responses.

\section{The Organisation of Cartels: Systems of Coordination, Compensation and Monitoring}

Cartel stability is enabled by systems of coordination, compensation and monitoring in all cases, as expected from both the economic and the social approach. Bid-rigging cartels use cover pricing and phases-of-the-moon systems. Firms inform each other on new incoming requests from potential and existing clients, while others respond when they receive the same request. Agreements are made on a specific project, and firms divide the work, communicating their prices and offers prior to submitting them in a tender procedure. They typically agree on who will obtain the tender, and the rest will submit a higher price. The firms themselves often document divided projects and clients. Based on this overview, they make use of compensations to even out disparities. To do this, firms can use false invoices, by which goods and services are billed that did not actually take place. In some cases, discounts for mutual deliveries are used to compensate. In addition, some bid-rigging cartels use a phases-of-the-moon system to decide 
whose turn it is to acquire the next project or client. It is a form of bid rotation by taking turns. Less communication is needed this way, leading to less potential written evidence of communication. Here is an example of how such a system can operate:

'We kept an overview in Excel. It was quite simple. Name of the tender, names of the suppliers [cartelists], their prices and the name of who got the tender. Those firms involved in the specific tender kept score, they noted the price on which the tender was assigned. An example: if there were three suppliers, one would have received work for $€ 70,000$, the other for $€ 80,000$ and the third for $€ 30,000$; then the next project would be for the one with $€ 30,000$. The lowest in the list came first.' (5)

There are also instances of cover pricing; purposely submitting a higher price than other firms. This is also referred to as 'borrowing prices' or courtesy bidding, which is used to stay in the loop and remain visible to potential clients, while lacking the capacity to actually execute the work. Cover pricing is a form of bid-rigging that takes place more decentralised and ad hoc.

Price-fixing cartels usually organise a number of meetings to set minimum prices or increase prices regarding a certain product or service. Minimum pricelists and standard client letters are used. In one example, producers meet twice a year to discuss and fix prices. As well as the means to increase prices, cartel members also discuss the timing of announcing the surcharge.

Other cases include market division cartels, dividing market shares and geographical allocation. These cartels use client lists, turnover lists, market-sharing lists, and geographical distributions. Dividing clients, often referred to by firms as 'respecting clients', is most common among the selected cases. One of the cartelists explains the use of client lists as follows:

'Goal of the list is to respect each others' A-relation customers. This means that if I received an order from someone else's A-relation client, I at least had to apply the price lists. And we did. The other one would then have the possibility to underprice that offer to manipulate the order in their direction'.

Cartels show a learning ability when it comes to effective coordination. In the next example, firms develop and professionalise their coordination system through trial and error. Initially they have a simple system: firms report orders of a certain size at a central contact point, discuss who is to be given the order and divide the work accordingly. However, as in most of the cases, firms need some form of compensation to even out disparities that would build up over time and were not in line with the mutual agreement. To compensate for this, firms would prefer orders, but sometimes also needed to apply financial transactions. However, this led to practical issues resulting in a flexible compensation rule, noted in the minutes of one of their meetings. This example illustrates how cartelists manage to negotiate a solution as well as how firms choose the desire for stability over financial gain:

'Because no member of the cartel could ever deliver exactly in accordance with the preestablished market shares, and it is considered undesirable for members to transfer money to one another as if they were bankers, an agreement is established including that compensation is not needed for over- or under-exceeding 5\% of the market share'. (4)

Other cases also illustrate this point. In case 14, firms divided national regions, and every cartelist was committed to refer potential clients to the firm that was active in that area. 
However, firms did not always succeed in referring clients. If clients went against being referred, the firm that originally received the order accepted the offer, hereby violating the original allocation agreement. For this situation, the cartel introduced a rule: if a client from another region was contracted, the firm owed $2 \%$ of that contract to the cartelist who 'owned' that region. Cases 4 and 14 are good illustrations of the coordination process in most cases, for two reasons. Firstly, it shows how parties can prevent resentment or conflicts by compensating according to what is perceived as 'just'. Secondly, it demonstrates how cartelists evaluate and negotiate in order to establish internal rules and agreements. Both examples of the informal rules that emerge from collective bargaining in the absence of formal legal means. Cartel rules can clearly be a result of social norms in a sector, as in the example of 'respecting clients'. Furthermore, the coordination process highlights the significance of communication and reciprocity. It illustrates how informal social rules can function as a far more powerful system to govern business conduct then formal legal rules (cf. Macaulay 1963). This also facilitates cartel stability, and makes internal punishment or retaliation less likely or irrelevant.

However, cartelists do monitor their agreements, which indicates some skepticism of firms with respect to the level of trust. We can distinguish different functions of these informal control mechanisms: firms collect information on the actions of other participants in the cartel; assess whether it is in line with the agreement; and decide what type of response should be applied to the cheating party. Cartels use two main mechanisms to monitor the agreement: meetings for reporting sales figures and so on, and independent administrators. In most cases, cartelists use some form of reporting figures, such as turnover, market shares, and prices. A managing director explains which issues are dealt with in these meetings:

'This was an evaluation meeting in which the outcome of dealer negotiations was addressed. Amongst other things, the following questions were dealt with: Did everyone manage to retain their clients? Did clients leave? Was an increase in prices established?'

Firms mention the social control function of cartel meetings. In the next example, one of the participants explains how meetings - in theory - would be superfluous. His statement, however, indicates the skepticism that most cartelists hold towards others' complying with the agreements:

'The role of pricelists is that they contain the price upon which others should overcharge in formulating their offer. Actually, the meetings would not have been necessary if every member had just abided by the pricelists, because that was defining.' (4)

Some cartels also use independent - third-party — administrators, sometimes referred to as a cartel 'secretary'. They are often retired executives, familiar with the market. They arrange practical matters, look after administration, and lead discussions or negotiations. One of these 'secretaries' explained that he organised the meetings, made reservations for venues, paid expenses in advance, took minutes of the meetings, and kept score of the general turnover numbers. Being an independent 'fixer', a secretary often functions not only as an administrator but also as an informal auditor. He monitors the cartel and fulfils a role in preventing possible disagreements or in mediating in the case of conflicts.

Firms are capable of coordinating and compensating in good standing and through collective bargaining within cartels. However, signs of informal control indicate a certain lack of trust. Notable from these examples is that, because of their need to operate underground, cartelists have to rely heavily on informal means of coordination as expected from the paradox 
of social embeddedness (Portes 2010). At the same time, however, cartelists tend to formalise their interactions heavily by clandestine bookkeeping, minutes of meetings and rules on mutual compensation. It remains unclear whether this is a function of trust or a lack of it.

\section{Responses: Cheating, Discussion and Conflict}

With internal monitoring also comes information on the behaviour of other cartelists. This information sometimes reveals cheating by one or more cartel members. When parties do not communicate regularly, suspicions of cheating arise, resulting in mutual disagreements and irritation. One of the firms openly raised questions on the level of internal compliance in the cartel in the following example, documented in internal correspondence between cartel members:

'Member[name club], [C] is right — we report everything that has to be reported, but we also observe from the order of the numbers [phases-of-the-moon system] that there seem to be only two companies that still report. The rest of them do nothing or keep quiet. Especially now, when times are tough, it is useful and necessary that we keep in touch (...). That's what we agreed upon. Or is [serial number of environmental certification these companies require to do business in this market] the end-all of the [name club]? This can't be true. Show some personality and guts - this attitude leads to nothing, to nothing at all.' (3)

Third-party fixers also notice internal struggles that occur in the context of collective meetings. The 'secretary' in the following example explains how he had a mitigating role in a dispute that derived from episodes of mutual cheating:

'I would tell them to stop arguing. (...) I believe that firms deviated a lot from the established pricelists. Everyone did. One would be left with the impression "they exchange everything, we all go home, and everyone does something else instead"'. (4)

In addition to third-party fixers, other cartel participants can fulfil a conciliatory role in the event of internal disagreements. A managing director explains:

'Arguments could escalate quickly because somebody had taken someone else's Arelation customer, for instance. If others saw this happening, they would adopt the role of mediator between parties in the meeting'. (1)

The next example also shows how firms can overcome conflicts bilaterally through communicating and showing a willingness to settle. This is a segment of a wiretapped conversation between cartelists as part of a police file, also used in the administrative procedure by the Dutch competition authority. It reflects a conversation held after an episode of cheating on the agreement by one of the parties:

'[A:] Guys, if this is the way we are going to do business, every man for himself, you know what's going to happen, right? The price will only go down and, well, quite frankly, I can of course go way down. I don't want to do this, but you just wait and see [B:]. You know, let us be wise. We should just return to the way we did business before, in everybody's best interest. We should take for granted that mistakes will be made, but we should set aside our feelings and trust each other's word'. (12)

These cases show how cheating is noticed by others in the cartel, and can lead to disagreements. However, cheating can also occur without being detected. In the following 
example, one of the cartelists explains how they would manipulate the information presented to others:

'It was a statement of the auditor that indicated how many square metres [name company] had supplied in the previous year. We would manipulate this statement and present it in the meeting. We blurred out the [type of product] that wasn't relevant to the cartel. We would leave the total amount, but replace the attachments with the amounts we had reported earlier'. (1).

These four cases demonstrate that despite sophisticated coordination systems, cheating occurs and can result in conflict. Although negotiations and mediating 'fixers' can help to overcome most conflicts, thus stabilising the cartel, in some cases this does not suffice. The following example, also from case 1 , shows how multiple attempts to overcome a lack of trust can ultimately fail. One of the managing directors provides a brief history of the cartel's internal struggles:

'In the autumn of 2002, the tension between [V] and [B] escalated again. [B] was accused in connection with several matters. I had a conversation on this matter with [V]. As a result of this conversation, [V] even called a director of [B]. I was upset about this, and then ended everything in December. (...) I think [V] eventually apologised in, I think, March 2003. We then sat back at the negotiation table. Everything was already falling apart anyway; [B] was doing his own thing. There had been a meeting in April 2003, and we concluded: "Guys, we have to stop. This is pointless." The stupid thing was that you were better off if you weren't sitting at the table, because then you wouldn't have to decrease your volume of production. As the biggest party, [V] had the greatest interest in keeping the thing together. You would have a really disproportional attendance at the table. We then finally quit.' (1)

\section{Outcome: Breaking up is Hard}

Based on the documents and the interviews with enforcement officials, it is not always possible to determine whether cartels in the selected cases actually ceased their activities, and, if so, whether this took place before, during or after the administrative procedures. As previously mentioned, however, 'internal violations' involving cartel agreements are mostly resolved at an early stage, ex ante, by mutual compensations, negotiations and mediation. In the last example, we saw how cheating could eventually lead to the demise of the cartel.

Nevertheless, based on the case material, there is reason to believe that on numerous occasions ending the cartel was not an easy decision. It was rarely due to explicit pressure and intimidation, and more often because of existing loyalties towards 'co-competitors', as illustrated by a quote from one of the directors:

'Again, I declare that we decided internally, with the introduction of the new Dutch competition law, to cease our activities. We did not succeed. We should have distanced ourselves from these activities. I urged this several times and was sometimes pressured by other firms to continue with the agreements. (12)

This example underlines what other scholars have pointed out: taking part in cartels is not a voluntary and purely instrumental decision, but is embedded in social 
reality that includes existing loyalties to industry peers in markets and within firms (Parker 2012). Breaking with the cartel was often also difficult because of the mutual dependencies that had evolved as a result of working closely with others for years. When one relies on informal systems and methods for doing business, it is not easy to reject them overnight for the sake of continuation of your business. This is illustrated in the following example:

"Recently I have said "no" on five or six occasions; the reason for saying "yes" again to future agreements [collusive tendering] was that I would also be included in the market if they received an order. If I say "no" too often, I'm sure to be excluded by them in the future. If I say "yes", however, this also creates possibilities for me. It's give-and-take in this business'. (12)

Reciprocity is a powerful market mechanism. It means that one might become a 'prisoner' of the system, entangled in mutual rights and obligations that make it harder to say goodbye (Van de Bunt 2010; Hertogh 2005). The uncertainty of a competitive market-smaller margins, downward price levels and so on-can also function as a push factor into continuing the cartel. This can result in cartelists, that had become competitors, to become cartelists again. This is illustrated by the following example:

'In March 2003 we as a company said "we should stop". It was illegal then, and it's illegal now. We have to learn to reason from the cost price plus leeway. After the summer of 2003 (fall) [company B] frontally attacked [company A]. [A] counter-attacked. Prices dropped dramatically and [A] yielded in a lot of orders that autumn. Then [B] took the initiative again to sit back at the negotiating table and said this was not workable; we are giving away everything to the market'. (1)

\section{Conclusions}

This study highlights how firms in the selected cases manage their cartels in the absence of law. The focus of this article has been on the internal structure of cartels, with regard to how firms are able to stabilise their cartel. The research question was How do informal coordinating mechanisms enable cartel stability outside the scope of formal legal control and what role does trust play? Two different perspectives were identified in the existing literature: an economic approach departing from the assumption of a lack of trust and a need for monitoring and retaliation, and a social approach departing from the assumption of mutual trust and the use of negotiation and mediation. Elements from both ideal types occurred in the selected cases.

On the one hand, the cases demonstrate the importance of informal social mechanisms for the 'successful' operation of cartels. Means of coordination and compensation-meetings, informal rules, and mutual debts-were established between firms through communication and reciprocity. The cases thereby confirmed the paradox of social embeddedness: namely, the need to operate secretly forces cartelists to rely heavily on social ties through informal means of coordination. Furthermore, mutual rights and obligations make parties interdependent, and reciprocity can function as a 
powerful market mechanism. This stabilises and strengthens cartels, and makes it hard for firms to end existing agreements. ${ }^{12}$

On the other hand, third-party auditors and the formalisation of agreements in writing also indicate a lack of trust: conflicts occurred in some cases, and parties sometimes responded through retaliation. However, retaliation appears more likely to lead to the end of the cartel rather than stabilising it. In light of conflicts, the dominant strategy seems to be not to punish other cartel members. In contrast, firms are often able to overcome mutual disagreements by means of negotiation and compensation. Moreover, most cases do not involve explicit episodes of conflict, confirming the preventative effect imposed by the systems of coordination and compensation. This is comparable to findings on drug markets, where retaliation is found to be a costly business tool and negotiation and toleration are common (Jacques and Wright 2008, 2011; Zaitch 2005).

The results emphasise that in order to explain cartel stability we need to consider the social embeddedness and the importance of social mechanisms that induce trust. Trust and a lack of trust both play a role in how firms manage and shape their cartels. In a theoretical sense, it remains a chicken and egg situation, because the formalisation of cartel agreements - clandestine bookkeeping, minutes of meetings, and rules on mutual compensations - can express both mutual trust or a lack of it. Both elements are clearly hard to disentangle, and such an exercise harms the complexity of the social reality of cartels. In this regard, the economic approach overlooks the fact that-given the participants' proper response - conflicts can prove to be an opportunity to strengthen the cartel, and they pan out to be a source of stability instead of instability. This is also referred to as the 'cleansing' function of social conflicts (Coser 1956). In these cases, cartels will be more difficult to break up, even when facing the threat of formal legal control (enforcement) or changing market conditions (Levenstein and Suslow 2011).

The results illustrate the importance of mutual dependencies between competitors and the use of informal social mechanisms to build trust and to stabilise cartels. This enables even relatively large groups of firms to cooperate effectively (e.g. case 12, 14 firms and a duration of nine years, case 7, 15 firms and a duration of seven years). The cases thereby show how an economic model provides an incomplete explanation for cartel stability and calls for incorporating a different approach to explain how cartel stability operates. Furthermore, this calls for incorporating a social perspective in competition law and policy, in which the influence of economic assumptions is widespread.

\section{Limitations}

It is difficult to determine the perspective of cartelists when their statements and testimonies have to be derived from secondary sources collected in the context of administrative procedures. Some issues, therefore - such as the significance of reputation-are less well documented. The data also did not always provide a definitive answer to whether the detected cartel had actually ended. This is an important question, because there is reason to believe that mutual conflicts and detection can also give rise to cartels beginning or starting anew. This

\footnotetext{
${ }^{12}$ In addition to these findings, it is noted that social capital, strong social ties and trust are often considered desirable in light of growth and economic value (cf. De Bliek 2015). However, these mechanisms can also have less desirable consequences. The strong ties in a social group such as a business cartel can benefit its members but exclude others from access. Moreover, it can limit and restrict the individual freedom of its members (Parker 2012; Portes 2010: 39).
} 
could indicate a learning ability in prosecuted firms in addition to a 'stronger-through-conflict' cooperation with other firms in their market. Large-scale cartel recidivism on an international and European level also supports this view (Connor and Helmers 2007; Connor 2010). However, the level of recidivism is yet to be established with regard to the Dutch situation, and more careful consideration of the 'cleansing function of social conflict' is needed.

This article has discussed only the internal threat of cheating within cartels. Other threats, like defection by insiders (whistleblowers) or detection by outsiders, have not been addressed. The material on detected cartels does not provide this inside information on considerations of firms that blew the whistle on the cartel in exchange for immunity or a waiver of prosecution.

Another issue raised by this study concerns the strain between concealment of conduct and coordination, as was pointed out by the formalisation of agreements through minutes of meetings, bookkeeping and so on. Communication and exchanges between firms in a cartel are underestimated (Grout and Sonderegger 2005). Communication seems to play a significant role in cartel stability, which might suggest that cartelists will engage in overtly collusive practices, in contrast to what might be expected from their need to conceal their cartel. This generates further questions surrounding cartel stability; for instance, what will prevail - the need to coordinate or the need to conceal? For further research on these issues, it is recommended to interview insiders such as compliance officers, in-house or external lawyers, or general managers of businesses confronted by or involved in cartel infringements.

Acknowledgments The author thanks Henk van de Bunt, Judith van Erp, Clarissa Meerts, Lisa van Reemst, Gerald Hopster and the anonymous reviewers for their comments on an earlier version of this article.

\section{Compliance with Ethical standards}

Funding This work was funded by the Netherlands Organisation for Scientific Research (NWO), MaGW Research Talent 2014, grant number 406-14-027.

Open Access This article is distributed under the terms of the Creative Commons Attribution 4.0 International License (http://creativecommons.org/licenses/by/4.0/), which permits unrestricted use, distribution, and reproduction in any medium, provided you give appropriate credit to the original author(s) and the source, provide a link to the Creative Commons license, and indicate if changes were made.

\section{References}

Agnew, R., Piquero, N. L., \& Cullen, F. T. (2009). General strain theory and white-collar crime. In The criminology of white-collar crime (pp. 35-60). New York: Springer.

Ashenfelter, O., \& Graddy, K. (2005). Anatomy of the rise and fall of a price-fixing conspiracy: auctions at Sotheby's and Christie's. Journal of Competition Law and Economics, 1(1), 3-20.

Ayres, I. (1987). How cartels punish: a structural theory of self-enforcing collusion. Colombia Law Review, 87, 295-325.

Beaton-Wells, C. (2008). The politics of cartel criminalisation: a pessimistic view from Australia. European Competition Law Review (E.C.L.R), 29(3), 185-195.

Beaton-Wells, C., \& Haines, F. (2010). The Australian Conversion: How the Case for Cartel Criminalisation Was Made. New Journal of European Criminal Law, 4(1), 499-521.

Black, D. (1983). Crime as social control. American Sociological Review, 48, 34- 45.

Black, D. (1984). Social control as a dependent variable. Toward A General Theory of Social Control, 1, 1-36. Coleman, J. S. (1988). Social capital in the creation of human capital. American journal of sociology, S95-S120. Connor, J. M. (2001). Global Price Fixing: Our Customers are the Enemy. Dordrecht: Kluwer.

Connor, J. M. (2010). Recidivism Revealed: Private International Cartels 1991-2009. Available at SSRN 1688508 
Connor, J. M., \& Helmers, C. G. (2007). Statistics on modern private international cartels, 1990-2005.

Coser, L. A. (1956). The functions of social conflict (Vol. 9). Routledge.

de Bliek, R. (2015). Empirical studies on the Economic Impact of Trust. Rotterdam: ERIM.

Eichenwald, K. (2001). The informant: a true story. New York: Broadway Books.

Ellickson, R. (1991). Order without law: how neighbors resolve disputes. Cambridge: Harvard University Press.

Friedrichs, D.O. (2010). Trusted criminals, White Collar Crime in Contemporary Society. Belmont: Wadsworth.

Fukuyama, F. (1995). Trust: The social virtues and the creation of prosperity. London: Penguin.

Fukuyama, F. (1997). The end of order. London: Social Market Foundation.

Geis, G. (1987). White Collar Crime: The Heavy Electrical Equipment Antitrust Cases of 1961. In M. D. Ermann \& R. J. Lundmann (Eds.), Corporate and Governmental Deviance: Problems of Organizational Behavior in Contemporary Society (pp. 111-130). New York: Oxford University Press.

Granovetter, M. (1985). Economic action and social structure: the problem of embeddedness. American journal of sociology, 481-510.

Granovetter, M. (1993). The nature of economic relationships. In R. Swedberg (Ed.), Explorations in Economic Sociology (pp. 3-41). New York: Russel Sage Foundation.

Green, E. J., \& Porter, R. H. (1984). Noncooperative collusion under imperfect price information. Econometrica, $52,87-100$.

Grossman, P. Z. (1996). The dynamics of a stable cartel: the Railroad Express 1851-1913. Economic Inquiry, $34(2), 220-236$.

Grout, P., \& Sonderegger, S. (2005). Predicting cartels. UK: Office of Fair Trading.

Haines, F., \& Beaton-Wells, C. (2012). Ambiguities in criminalising business conduct: cartels as a case study. British Journal of Criminology, 52(5), 953-973.

Harding, C. (2006). Business collusion as a criminological phenomenon: exploring the global criminalisation of business cartels. Critical Criminology, 14, 181-205.

Harding, C., \& Joshua, J. (2003). Regulating cartels in Europe. New York: Oxford University Press.

Harding, C., Beaton-Wells, C., Edwards, J. (2015). Leniency and Criminal Sanctions in Anti-Cartel Enforcement: Happily Married or Uneasy Bedfellows? In: C. Beaton-Wells, \& C. Tran (Eds.). (2015). Anti-Cartel Enforcement in a Contemporary Age: Leniency Religion. Bloomsbury Publishing.

Harrington, J. E. (2006). How do cartels operate? Now Publishers Inc.

Hertogh, M. (2005). Van naleving naar beleving van regels. Bouwwereld en bouwfraude vanuit een rechtssociologisch perspectief. In T. Barkhuysen, W. Den Ouden, \& J. E. M. Polak (Eds.), Recht realiseren. Bijdragen rond het thema adequate naleving van rechtsregels. Deventer: Kluwer.

Hinloopen, J. (2006). Internal cartel stability with time-dependent detection probabilities. International Journal of Industrial Organization, 24(6), 1213-1229.

Jacques, S., \& Wright, R. (2008). The relevance of peace to studies of drug market violence. Criminology, 46(1), 221-254.

Jacques, S., \& Wright, R. (2011). Informal control and illicit drug trade. Criminology, 49(3), 729-765.

Jamieson, K. (1994). The Organization of Corporate Crime: Dynamics of Antitrust Violation. London: Sage.

Leslie, C. R. (2004). Trust, distrust, and antitrust. Texas Law Review, 82(3).

Leslie, C. R. (2008). Cartels, Agency Costs, and Finding Virtue in Faithless Agents. William \& Mary Law Review, 49(5).

Levenstein, M. C., \& Suslow, V. Y. (2006). What determines cartel success? Journal of Economic Literature, XLIV, 43-95.

Levenstein, M. C., \& Suslow, V. Y. (2011). Breaking up is hard to do: Determinants of cartel duration. Journal of Law and Economics, 54(2), 455-492.

Macaulay, S. (1963). Non-contractual relations in business: a preliminary study. American sociological review, 55-67.

Macaulay, S. (2013). The Real and the Paper Deal: Empirical Pictures of Relationships, Complexity and the Urge for Transparent Simple Rules. Revisiting the Contracts Scholarship of Stewart Macaulay: On the Empirical and the Lyrical, 35.

Ottow, A. T. (2012). Europeanization of the supervision of competitive markets. European Public Law, 18(1), 191-221.

Paoli, L. (2003). Mafia brotherhoods: Organized crime, Italian style. New York: Oxford University Press.

Parker, C. (2012). Economic rationalities of governance and ambiguity in the criminalization of cartels. British Journal of Criminology, 52(5), 974-996.

Paternoster, R., \& Simpson, S. (1996). Sanction threats and appeals to morality: Testing a rational choice model of corporate crime. Law and Society Review, 549-583.

Piquero, N. L. (2012). The only thing we have to fear is fear itself: investigating the relationship between fear of falling and white-collar crime. Crime \& Delinquency, 58(3), 362-379. 
Piquero, N. L., \& Weisburd, D. (2009). Developmental trajectories of white-collar crime. In The criminology of white-collar crime (pp. 153-171). New York: Springer.

Portes, A. (2010). Economic sociology: a systematic inquiry. Princeton University Press.

Posner, E. A. (2009). Law and social norms. Harvard University Press.

Putnam, R. D. (1995). Bowling alone: America's declining social capital. Journal of Democracy, 6(1), 65-78.

Putnam, R. D. (2000). Bowling alone: the collapse and the revival of American democracy. New York: Simon \& Schuster.

Rapoport, A., \& Chammah, A. M. (1965). Prisoner's dilemma: A study in conflict and cooperation (Vol. 165). University of Michigan Press.

Shaffer, G., \& Nesbitt, N. H. (2011). Criminalizing cartels: a global trend? Sedona Conference Journal, 12, 1126.

Sonnenfeld, J., \& Lawrence, P. R. (1978). Why do companies succumb to price fixing? Harvard Business Review, 56(4), 145-157.

Spagnolo, G. (2000). Optimal Leniency Programs. FEEM Working Paper No. 42.2000

Spar, D. L. (1994). The cooperative edge: The Internal politics of international cartels. Cornell University Press.

Stephan, A. (2010). Cartel laws undermined: Corruption, social norms, and collectivist business cultures. Journal of Law and Society, 37(2), 345-367.

Stewart, D. (2007). Price Fixing. In J. Gerber \& E. Jensen (Eds.), Encyclopedia of white-collar crime (pp. 238240). Westport CT: Greenwood Press.

Stigler, G. J. (1968). Price and non-price competition. Journal of Political Economy, 149-154.

Van De Bunt, H. (2010). Walls of secrecy and silence. Criminology \& Public Policy, 9(3), 435-453.

Van Erp, J. G. (2008). Reputational sanctions in Private and Public regulation. Erasmus Law Review, 2008(5), $145-163$.

Weisburd, D., \& Waring, E. (2001). White-collar crime and criminal careers. Cambridge University Press.

Zaitch, D. (2002). Trafficking cocaine: Colombian drug entrepeneurs in the Netherlands. Den Haag: Kluwer Law International.

Zaitch, D. (2005). The ambiguity of violence, secrecy, and trust among Colombian drug entrepreneurs. Journal of Drug Issues, 35(1), 201-228. 